\title{
Divergence of dominant factors in soil microbial communities and functions in forest ecosystems along a climatic gradient
}

\author{
Zhiwei Xu ${ }^{1,2}$, Guirui $\mathbf{Y u}^{3,4}$, Xinyu Zhang ${ }^{3,4}$, Nianpeng $\mathrm{He}^{3,4}$, Qiufeng Wang ${ }^{3,4}$, Shengzhong Wang ${ }^{1,2}$, Xiaofeng $\mathbf{X u}^{5}$, \\ Ruili Wang 6 , and Ning Zhao ${ }^{7}$ \\ ${ }^{1}$ Institute for Peat and Mire Research, College of Geographical Sciences, Northeast Normal University, \\ Changchun, 130024, China \\ ${ }^{2}$ Jilin Provincial Key Laboratory for Wetland Ecological Processes and Environmental Change in the \\ Changbai Mountains, Changchun, 130024, China \\ ${ }^{3}$ Key Laboratory of Ecosystem Network Observation and Modeling, Institute of Geographic Sciences and \\ Natural Resources Research, Chinese Academy of Sciences, Beijing, 100101,China \\ ${ }^{4}$ College of Resources and Environment, University of Chinese Academy of Sciences, Beijing, 100190, China \\ ${ }^{5}$ Biology Department, San Diego State University, San Diego, CA 92182, USA \\ ${ }^{6}$ College of Forestry, Northwest A\&F University, Yangling, Shaanxi Province, 712100, China \\ ${ }^{7}$ Cold and Arid Regions Environmental and Engineering Research Institute, Chinese Academy of Sciences, \\ Lanzhou, 730000, China
}

Correspondence: Guirui Yu (yugr@igsnrr.ac.cn) and Xinyu Zhang (zhangxy@igsnrr.ac.cn)

Received: 10 June 2017 - Discussion started: 14 July 2017

Revised: 24 November 2017 - Accepted: 29 January 2018 - Published: 1 March 2018

\begin{abstract}
Soil microorganisms play an important role in regulating nutrient cycling in terrestrial ecosystems. Most of the studies conducted thus far have been confined to a single forest biome or have focused on one or two controlling factors, and few have dealt with the integrated effects of climate, vegetation, and soil substrate availability on soil microbial communities and functions among different forests. In this study, we used phospholipid-derived fatty acid (PLFA) analysis to investigate soil microbial community structure and extracellular enzymatic activities to evaluate the functional potential of soil microbes of different types of forests in three different climatic zones along the north-south transect in eastern China (NSTEC). Both climate and forest type had significant effects on soil enzyme activities and microbial communities with considerable interactive effects. Except for soil acid phosphatase (AP), the other three enzyme activities were much higher in the warm temperate zone than in the temperate and the subtropical climate zones. The soil total PLFAs and bacteria were much higher in the temperate zone than in the warm temperate and the subtropical zones. The soil $\beta$ glucosidase (BG) and $\mathrm{N}$-acetylglucosaminidase (NAG) activities were highest in the coniferous forest. Except for the
\end{abstract}

soil fungi and fungi-bacteria $(\mathrm{F} / \mathrm{B})$, the different groups of microbial PLFAs were much higher in the conifer broadleaved mixed forests than in the coniferous forests and the broad-leaved forests. In general, soil enzyme activities and microbial PLFAs were higher in primary forests than in secondary forests in temperate and warm temperate regions. In the subtropical region, soil enzyme activities were lower in the primary forests than in the secondary forests and microbial PLFAs did not differ significantly between primary and secondary forests. Different compositions of the tree species may cause variations in soil microbial communities and enzyme activities. Our results showed that the main controls on soil microbes and functions vary in different climatic zones and that the effects of soil moisture content, soil temperature, clay content, and the soil N / P ratio were considerable. This information will add value to the modeling of microbial processes and will contribute to carbon cycling in large-scale carbon models. 


\section{Introduction}

There is a growing awareness that above- and belowground interactions make an essential contribution to ecosystem function (van Dam and Heil, 2011). Variations in soil microbial diversity and community structure have a strong influence on soil organic matter turnover and may have an impact on the function of a given ecosystem (Baumann et al., 2013). For example, mycorrhizal fungi and nitrogen (N) fixing bacteria are responsible for $80 \%$ of all $\mathrm{N}$ and up to $75 \%$ of phosphorus $(\mathrm{P})$ that is acquired by plants annually (van der Heijden et al., 2008). Therefore, it is important to study the composition and enzyme activities of soil microbial communities to obtain an improved understanding of the mechanisms that control soil organic carbon dynamics in different forest ecosystems.

Vegetation composition may alter soil physicochemical properties by changing the quantity and quality of plant litter, which further influence microbial community composition and function (Ushio et al., 2010). There is increasing evidence that vegetation types influence the structure and functions of the soil microbial community (Zheng et al., 2015). Differences in microbial communities, as represented by phospholipid-derived fatty acids (PLFAs), have also been reported among adjacent maple, beech, hornbeam, lime, and ash forests in Germany (Scheibe et al., 2015) and among forests of four conifer species in coastal British Columbia (Grayston and Prescott, 2005). From a functional perspective, both soil acid phosphatase and $\beta$-glucosidase activities were higher in a monsoon evergreen broadleaf forest than in a Masson pine forest (Zheng et al., 2015). However, vegetation type does not always have an effect on the composition of the soil microbial community. Hannam et al. (2006) reported that the microbial community composition of a whitespruce-dominated forest differed substantially from that of an aspen-dominated stand but was similar to that of a mixed stand with equivalent proportions of deciduous and coniferous trees. Most of the studies conducted thus far have been confined to a single forest biome or have focused on one or two controlling factors (Ultra et al., 2013), and few have dealt with the integrated effects of climate, vegetation, and soil substrate availability on soil microbial communities and functions in different forest biomes.

Soil microbial communities and enzyme activities can be influenced by an array of factors, such as climate (Xu et al., 2015), vegetation types (Urbanová et al., 2015), plant diversity (Li et al., 2015), and physicochemical soil properties (Tripathi et al., 2015). The links between the diversity of plant and soil microbial communities and enzyme activities are widely acknowledged (Chung et al., 2007). The composition of the vegetation species can be used to successfully predict the soil microbial community (Mitchell et al., 2010). Soils with different vegetation types develop distinct physicochemical properties that will have pronounced effects on the structure and function of the soil microbial community
(Priha and Smolander, 1997). Soil organic matter is related to the variations in microbial activities and community function (Brockett et al., 2012). Soil pH (Shen et al., 2013), elemental stoichiometric ratios (Högberg et al., 2007), and nutrient status (Lauber et al., 2008) have also been identified as determinants of microbial community structure. However, we still do not know which mechanisms control the variability in the structure and functions of soil microbial communities within different groups of plant species (broadleaved and coniferous trees) on similar soil types within the same climatic region.

Forest soil microbial community structures and enzyme activities are influenced by different factors in different climatic zones. For example, Högberg et al. (2007) found that the soil microbial community composition in a boreal forest was strongly influenced by the soil carbon-to-nitrogen ratio $(\mathrm{C} / \mathrm{N})$ and the soil $\mathrm{pH}$. Studies in temperate forests have shown that dehydrogenase and urease were closely related to the mean air temperature, litter production, and nutrient availability (Kang et al., 2009). In addition, Hackl et al. (2005) reported that soil water availability was responsible for variability in the microbial community structure of temperate forests. Precipitation and soil moisture may be important controls on the structure of soil fungal communities of tropical forests (McGuire et al., 2012). However, there is a lack of well-defined information about the factors that influence the structure and functions of soil microbial communities in forests with different plant species (broadleaved and coniferous trees) across a range of climates and soils.

The north-south transect of eastern China (NSTEC) represents a latitudinal and climatic gradient. It is a unique belt in which vegetation ranges from boreal forest to tropical rain forest, depending on the local temperature and precipitation conditions. In this study we examined variations in the soil microbial communities and their functions in forests comprising different species (broadleaved and coniferous trees) in temperate, warm temperate, and tropical forest biomes along the NSTEC. The temperature and precipitation are different in these three climatic zones. We used information about the soil physicochemical properties, microbial community structure, and hydrolytic enzyme activities involved in $\mathrm{C}, \mathrm{N}$, and $\mathrm{P}$ transformations to explore how soil microbial communities and enzyme activities differed among different forest types in different climatic zones and to determine the influence of different environmental variables on the soil microbial communities and enzyme activities in different climatic zones.

\section{Materials and methods}

\subsection{Study area and soil sampling}

We chose three study sites, namely Liangshui (LS) in Northeast China, Taiyue Mountain (TY) in North China, and Dinghu Mountain (DH) in South China, along the NSTEC 


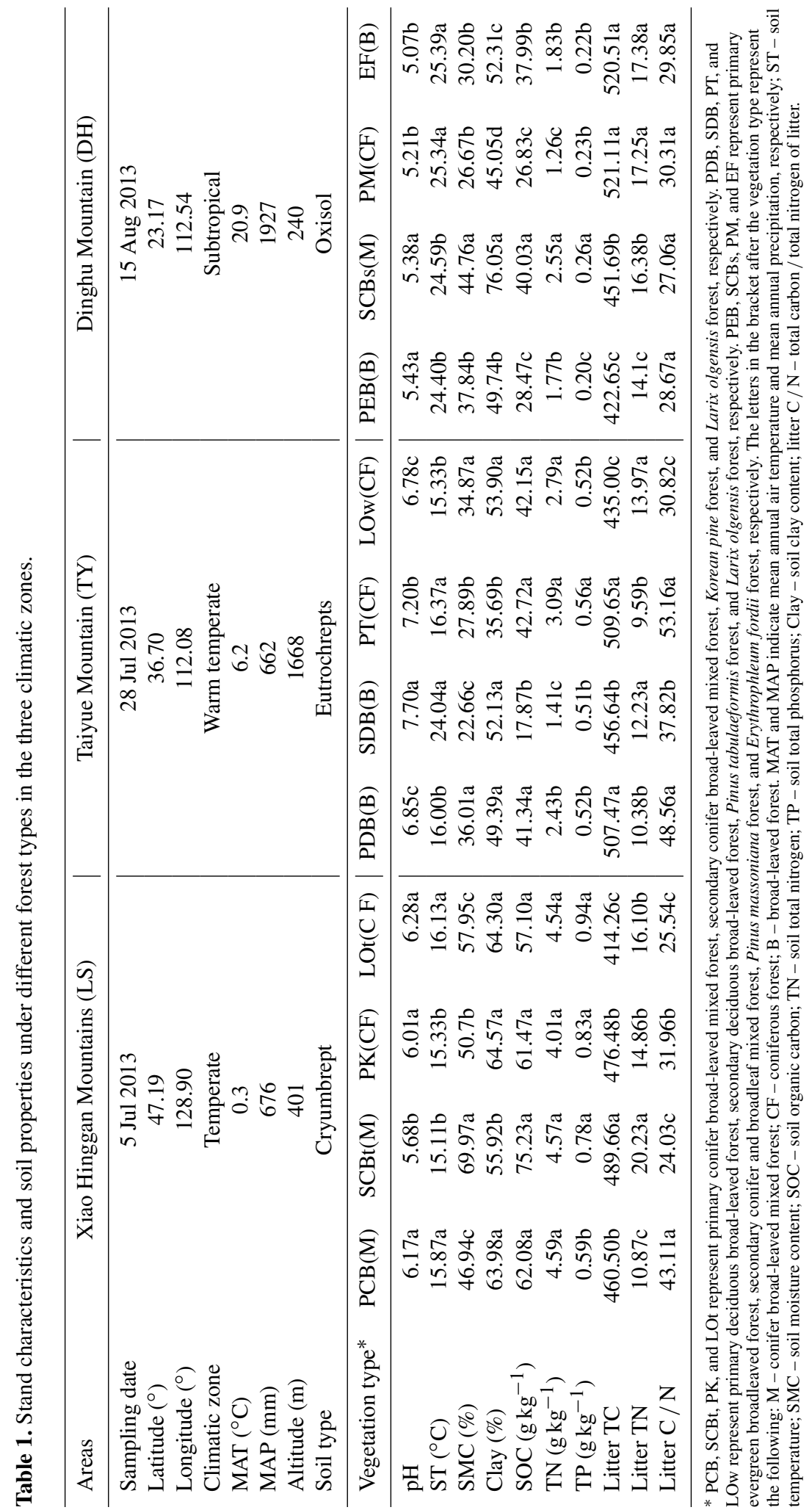


for field measurements and soil sampling. Both the air temperature and precipitation decrease from south to north along the NSTEC (Table 1).

We examined all the representative forest species in each climatic zone. In Liangshui, on the Xiao Hinggan Mountains, we sampled primary conifer broad-leaved mixed forest (PCB), secondary conifer broad-leaved mixed forest (SCBt), and two coniferous plantations, one of which was mainly $P i$ nus koraiensis (PK) while the other was Larix olgensis (LOt). On Taiyue Mountain, we sampled primary deciduous broadleaved forest (PDB), secondary deciduous broad-leaved forest (SDB), and two coniferous plantations, one of which was comprised mainly of Pinus tabulaeformis (PT) while the other was mainly Larix olgensis (LOw). On Dinghu Mountain, we sampled a primary evergreen broadleaved forest (Castanopsis chinensis, Cryptocarya chinensis, Cryptocarya concinna, Erythrophleum fordii, and Cyathea podophylla), secondary conifer and broadleaf mixed forest (Pinus massoniana, Schima superba), a coniferous plantation (Pinus massoniana), and an evergreen broadleaved plantation (Erythrophleum fordii) along a successional stage, hereafter referred to as PEB, SCBs, PM, and EF, respectively. The average temperature of the sampling month was $21.3,17.4$, $27.3^{\circ} \mathrm{C}$ with the relative humidity of $78,60-65$, and $83.5 \%$ in LS, TY, and DH, respectively. The sampling dates are 5 July, 28 July, and 15 August 2013 in LS, TY, and DH, respectively. The primary forests are zonal forests that reflect the regional climate and the others are zonal forests that reflect the extreme site conditions. Information about the climate, soil classification (Soil Survey Staff, 2010), and soil properties at each site is provided in Table 1.

Soil samples were collected at nine sampling sites along the NSTEC in July and August 2013. Each site had four independent plots in well-drained areas, which covered an area of $30 \mathrm{~m} \times 40 \mathrm{~m}$ and were at least $10 \mathrm{~m}$ apart. The vegetation composition of the four plots at each site was similar. Samples of mineral soil were collected from a depth of $0-10 \mathrm{~cm}$ at between 30 and 50 points in each plot along an S shape using a custom-made coring device with a diameter of $6 \mathrm{~cm}$. The aboveground standing biomass, dead plant parts, and litter were removed from each sampling point. These samples were pooled together as a composite sample. Visible roots and residues were removed and then the soil fractions of each sample were homogenized.

We stored the samples at $4{ }^{\circ} \mathrm{C}$ in a portable refrigerator during field sampling. Once returned to the laboratory, samples were stored at $4{ }^{\circ} \mathrm{C}$ before analysis. Soils were analyzed for enzyme activities and PLFAs in September 2013. The fresh soil samples were sieved through a $2 \mathrm{~mm}$ mesh and were subdivided into three subsamples. One subsample was stored at $4{ }^{\circ} \mathrm{C}$ until analyzed for soil enzyme activities and physical and chemical properties. The second was stored at $-20^{\circ} \mathrm{C}$ before analysis for microbial community structures. The third was air-dried and then sieved through a $0.25 \mathrm{~mm}$ mesh before soil organic carbon (SOC), soil total nitrogen
(TN), and soil total phosphorus (TP) analysis. The soil temperatures were measured in situ at the time of sampling. Soil moisture content (SMC) was measured gravimetrically on $20 \mathrm{~g}$ fresh soil that was oven-dried at $105^{\circ} \mathrm{C}$ to constant weight immediately on arrival at the laboratories at the study sites (Liu et al., 2012).

\subsection{Soil chemical analyses}

Soil $\mathrm{pH}$ was measured at a soil-to-water ratio of $1: 2.5$. TN concentrations were determined by dry combustion of ground samples (100 mesh) in a C / N analyzer (Elementar, Vario Max CN, Germany). The SOC concentrations were determined by dichromate oxidation and titration with ferrous ammonium sulfate (Huang et al., 2014). The litter total C (litter TC) and total N (litter TN) were determined with the same method that was used for soil TN. TP was determined with a flow injection autoanalyzer following digestion with $\mathrm{H}_{2} \mathrm{SO}_{4}-$ $\mathrm{HClO}_{4}$ (Huang et al., 2011). The soil clay fraction (hereafter referred to as Clay, comprised of particles $<53 \mu \mathrm{m}$ ) was separated by wet sieving and then freeze-dried (Six et al., 2000).

\subsection{Phospholipid fatty-acid and enzyme activity analysis}

Samples were analyzed for PLFAs using the method described by Bååth and Anderson (2003). After mild alkaline methanolysis to form fatty acid methyl esters (FAMEs), samples were then dissolved in hexane and analyzed with a DB-5 column in a gas chromatography mass spectroscopy (GCMS) system (Thermo TRACE GC Ultra ISQ). Total amounts of the different PLFA biomarkers were used to represent the different groups of soil microorganisms (Table S1). Taken together, the combination of bacterial, fungal, and actinomycic PLFA biomarkers represented the total PLFAs of the soil microbial community.

The activities of $\beta$-glucosidase (BG), $\quad \mathrm{N}$ acetylglucosaminidase (NAG), acid phosphatase (AP), and leucine aminopeptidase (LAP) were measured as outlined by Saiya-Cork et al. (2002). The microplates were incubated in the dark at $20^{\circ} \mathrm{C}$ for $4 \mathrm{~h}$. During the incubation, the incubation plates were shaken every hour to ensure the reaction mixtures were homogenous. Fluorescence was measured using a microplate fluorometer with $365 \mathrm{~nm}$ excitation and $450 \mathrm{~nm}$ emission filters (Synergy ${ }^{\mathrm{H} 4}$ Hybrid Reader, Synergy ${ }^{\mathrm{H} 4}$ BioTek, USA).

\subsection{Statistical analysis}

One-way analysis of variance (ANOVA) with a post hoc Tukey honest significant difference (HSD) test was used to test the differences between the soil and microbial properties in the various forests of the three climatic zones. All data were normality distributed. Two-way analysis was used to test the effect of climate and vegetation on the soil microbial properties. All ANOVA and two-way analyses were 
performed using SPSS 19.0 for Windows. Figures were generated using the Origin 8.0 package. Data are reported as the mean $\pm \mathrm{SE}$.

Redundancy analysis (RDA) was used to examine the relationships between the litter factors (litter TC, litter TN, litter C / N), soil biochemical variables (soil temperature (ST), $\mathrm{SMC}, \mathrm{pH}, \mathrm{C} / \mathrm{N}$, soil carbon-to-phosphorus ratio $(\mathrm{C} / \mathrm{P})$, soil nitrogen-to-phosphorus ratio (N/P), SOC, TN, TP), soil clay content (Clay), and the soil microbial community compositions and enzyme activities. Before redundancy analysis, we conducted forward selection of the environmental variables that were significantly correlated with variations in the microbial communities and enzyme activities using stepwise regression and the Monte Carlo permutation test that was similar to the multiple regression analysis. Stepwise regression and RDA were processed using the CANOCO software 4.5 (Ter Braak and Smilauer, 2002). The vectors of greater magnitude that formed smaller angles with an axis were more strongly correlated with that axis.

\section{Results}

\subsection{Soil enzyme activities in different vegetation types}

The soil enzyme activities were generally higher in the primary forests than in the secondary forests in temperate and warm temperate climatic zones (Fig. 1). However, in the subtropical climatic zone, soil enzyme activities were higher in the SCBs forest than in the PEB forest. The BG, NAG, and AP enzymes in the two soils of the PT and LOw in the warm temperate zone were significantly different (Fig. 1a, $\mathrm{b}, \mathrm{d})$. The soil BG and NAG activities were much higher in the coniferous forest than in the conifer broad-leaved mixed forests and the broad-leaved forests (Table S2). The soil AP enzyme activities were highest in the conifer broad-leaved mixed forests and lowest in the coniferous forests (Table S2).

Climate, a significant influence on the variations in soil enzyme activities $(P<0.0001)$, had more influence than forest type. The soil BG, NAG, and LAP activities were much higher in the warm temperate zone than in the temperate and the subtropical climate zones (Table S2). The AP activities were highest in the subtropical climate zone (Table S2). The effects of climate and forest type interactions were only significant for soil NAG $(P<0.0001)$ and AP activities $(P=0.035)$ (Tables $2, \mathrm{~S} 2)$. Forests within the same climatic zones had similar soil enzyme activities (Fig. S1 in the Supplement).

\subsection{Soil microbial community composition in different vegetation types}

Soil PLFAs were higher in the primary forest in the temperate and warm temperate zones than in the secondary forest. In the temperate zones, soil PLFAs were higher in the PCB forest than in the SCBt, PK, and LOt (Fig. 2a). In the warm
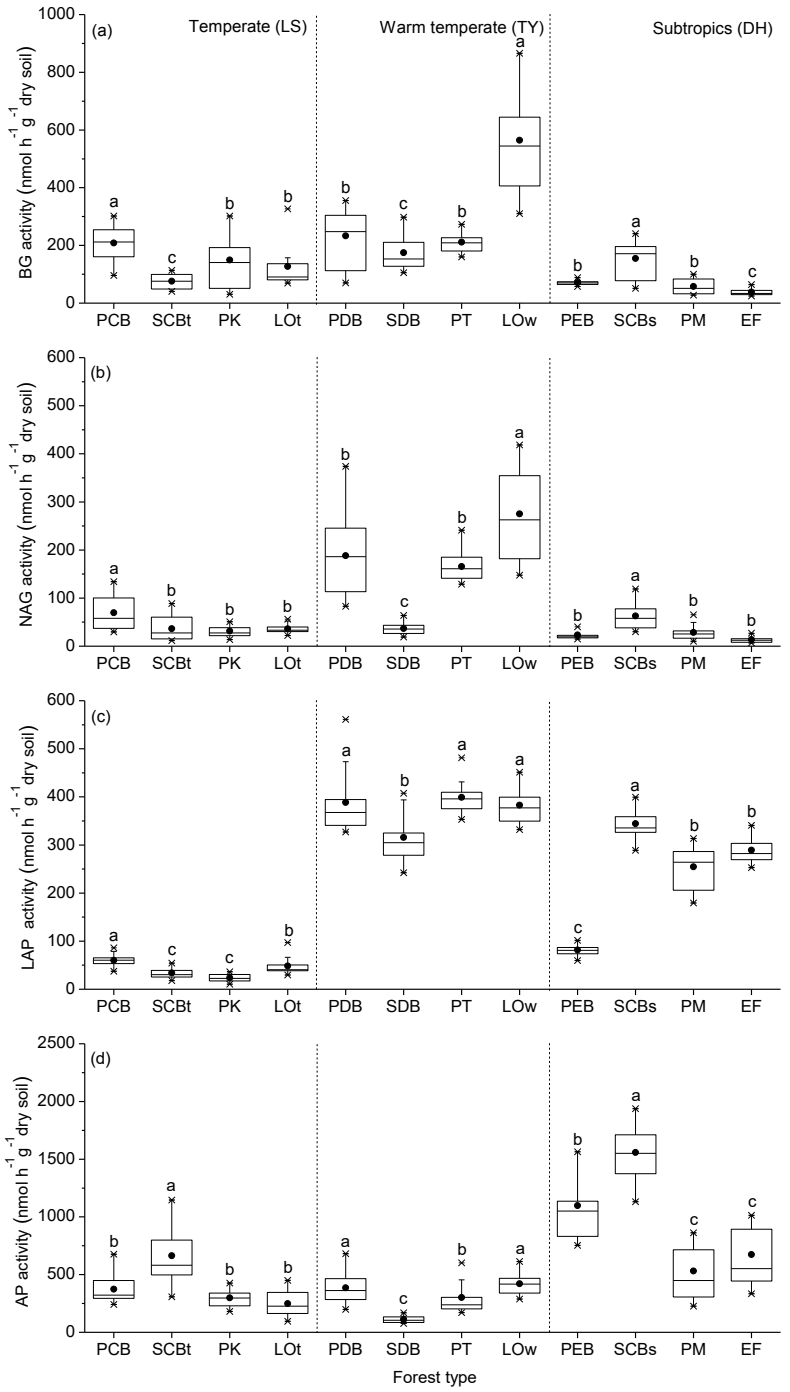

Figure 1. Soil enzyme activities under different forest types in different climatic zones. BG, b-1, 4-glucosidase; NAG, b-1,4$\mathrm{N}$-acetylglucosaminidase; LAP, leucine aminopeptidase; AP, acid phosphatase. Panels (a), (b), (c), and (d) represent the variations in the enzyme activities of BG, NAG, LAP, and AP, respectively. Different lowercase letters indicate significant differences between forests in the same climatic zone. The abbreviations of the sampling sites are shown in Table 1

temperate forests, total soil microbial PLFAs were highest in the LOw forest (Fig. 2b). In the subtropical zone, total, bacterial, and actinomycic PLFAs were higher in the PEB and SCBs forests than in the PM and EF forests (Fig. 2c). The forest type had a significant effect on the soil bacteria, fungi, gram-positive bacteria $\left(G^{+}\right)$, and gram-negative bacteria $\left(G^{-}\right)$PLFAs (Table 2). The soil total PLFAs, bacteria, $G^{+}, G^{-}$, and actinomycete were much higher in the conifer broad-leaved mixed forests than in the coniferous forests and the broad-leaved forests (Table S2). The soil fungi was high- 
Table 2. The effect of forest types and climate on the soil enzyme activities and PLFAs. The bold font means that the effect of forest types and climate were significant. tPLFA: total PLFA.

\begin{tabular}{llrr|rr|rr}
\hline \multirow{2}{*}{ Treatment } & \multicolumn{2}{c}{ Climate } & \multicolumn{2}{c}{ Forest type } & \multicolumn{2}{c}{ Climate $\times$ forest type } \\
\cline { 2 - 7 } & & $F$ & $P$ & $F$ & $P$ & $F$ & $P$ \\
\hline Enzyme activity & BG & $\mathbf{3 0 . 4 8 7}$ & $<\mathbf{0 . 0 0 0 1}$ & $\mathbf{6 . 8 5 2}$ & $\mathbf{0 . 0 0 3}$ & 3.105 & 0.056 \\
& NAG & $\mathbf{3 2 . 7 9 3}$ & $<\mathbf{0 . 0 0 0 1}$ & 5.183 & 0.10 & $\mathbf{3 . 6 3 5}$ & $\mathbf{0 . 0 3 5}$ \\
& LAP & $\mathbf{1 7 1 . 8 6 4}$ & $<\mathbf{0 . 0 0 0 1}$ & $\mathbf{1 6 . 3 6 4}$ & $<\mathbf{0 . 0 0 0 1}$ & 1.813 & 0.176 \\
& AP & $\mathbf{9 5 . 0 7 0}$ & $<\mathbf{0 . 0 0 0 1}$ & $\mathbf{4 8 . 1 1 7}$ & $<\mathbf{0 . 0 0 0 1}$ & $\mathbf{2 2 . 4 4 6}$ & $<\mathbf{0 . 0 0 0 1}$ \\
\hline PLFAs & tPLFA & $\mathbf{7 . 7 6 4}$ & $\mathbf{0 . 0 0 1}$ & 2.697 & 0.079 & $\mathbf{8 . 6 6 6}$ & $\mathbf{0 . 0 0 1}$ \\
& Bacteria & 2.796 & 0.073 & $\mathbf{4 . 9 2 1}$ & $\mathbf{0 . 0 1 2}$ & $\mathbf{8 . 3 5 7}$ & $\mathbf{0 . 0 0 1}$ \\
& Fungi & 8.002 & 0.001 & $\mathbf{2 1 . 2 5 5}$ & $<\mathbf{0 . 0 0 0 1}$ & $\mathbf{2 5 . 0 2 3}$ & $<\mathbf{0 . 0 0 0 1}$ \\
& Actinomycetes & 0.533 & 0.591 & 2.979 & 0.062 & $\mathbf{3 . 5 0 0}$ & $\mathbf{0 . 0 4 0}$ \\
& F / B & 3.731 & $\mathbf{0 . 0 3 2}$ & $\mathbf{1 5 . 5 0 2}$ & $<\mathbf{0 . 0 0 0 1}$ & $\mathbf{6 . 3 7 8}$ & $\mathbf{0 . 0 0 4}$ \\
$G^{+}$ & 0.603 & 0.552 & $\mathbf{3 . 3 9 5}$ & $\mathbf{0 . 0 4 3}$ & $\mathbf{5 . 9 3 4}$ & $\mathbf{0 . 0 0 5}$ \\
$G^{-}$ & $\mathbf{1 2 . 5 0 3}$ & $<\mathbf{0 . 0 0 0 1}$ & $\mathbf{6 . 8 9 0}$ & $\mathbf{0 . 0 0 3}$ & $\mathbf{1 1 . 1 0 6}$ & $<\mathbf{0 . 0 0 0 1}$ \\
& $G^{+} / G^{-}$ & 1.662 & 0.202 & 0.069 & 0.933 & 2.257 & 0.117 \\
\hline
\end{tabular}

The abbreviations of the variables included in this table are defined in the captions to Figs. 1 and 2.

est in the broad-leaved forest and lowest in the coniferous forest (Table S2).

With the exception of the soil $G^{+} / G^{-}$, the effects of the combination of climate and forest type on all soil PLFAs were significant and were stronger than the individual effects of either climate or forest type (Tables 2, S2). Climate had a significant effect on the total PLFAs, fungi, and $G^{-}$ $(P<0.0001)$ (Table 2). The soil total PLFAs, bacteria, $G^{+}$, and $G^{-}$were much higher in the temperate zone than in the warm temperate and the subtropical zones (Table S2). The fungi, F / B, and $G^{+} / G^{-}$were highest in the subtropical zone (Table S2). The soil microbial communities in the different forests in the three climate zones were generally unique (Figs. 4, S2).

\subsection{Relationships between soil enzyme activities and soil properties}

The variations in the soil enzyme activities in the 12 forests were significantly and positively correlated with soil nutrient ratios $(\mathrm{C} / \mathrm{P}$ and $\mathrm{N} / \mathrm{P}), \mathrm{ST}$, and litter TN $(P=0.002)$ but were negatively correlated with soil $\mathrm{pH}$ and $\mathrm{TP}(P=0.002)$ (Fig. S1). The litter C / N, litter TN, and SMC $(P=0.002)$ were the most important influences on the soil enzyme activity variations in the temperate forests, followed by ST, soil $\mathrm{N} / \mathrm{P}$, and soil TP (Fig. 3a). In the warm temperate forests, the variations in the soil enzyme activities were significantly and positively correlated with $\mathrm{ST}$ and soil $\mathrm{pH}(P=0.002)$ but were negatively correlated with SMC and soil nutrients (TN and SOC) (Fig. 3b). In the subtropical forests, soil enzyme activities were significantly and positively correlated with clay, SMC, soil TN, and TP ( $P=0.002)$, followed by soil nutrient ratios (Fig. 3c). These results indicate that the litter inputs, soil microclimate, and soil texture were the main drivers of variations in the soil enzyme activities in the temperate, warm temperate, and subtropics, respectively, with $\mathrm{ST}, \mathrm{pH}, \mathrm{SMC}$, and soil N / P as additional influences.

\subsection{Relationships between PLFA profiles and measured soil properties}

The variations in the soil microbial communities in the 12 forests were significantly and positively correlated with $\mathrm{ST}$, clay content, soil nutrient ratios $(\mathrm{C} / \mathrm{P}$ and $\mathrm{N} / \mathrm{P})$, and $\mathrm{TN}$ $(P=0.002)$ but were negatively correlated with litter TC $(P=0.002)$ (Fig. S2). In the temperate forests, the variations in the soil microbial community structure were strongly affected by the litter TN, litter TC, litter C / N, soil TP, and ST $(P=0.002)$ (Fig. 4a). In the warm temperate forests, the first axis of the RDA plot of the soil microbial community structure was significantly and positively correlated with ST $(P=0.002)$ but was negatively correlated with soil $\mathrm{N} / \mathrm{P}$, soil TN, soil C / P, and SOC ( $P=0.002$ ) (Fig. 4b). In subtropical forests, the variations in the soil microbial community structure were significantly and positively correlated with litter TC and ST $(P=0.002)$ but negatively correlated with SMC, soil C / P, soil N / P, and soil C / N ( $P=0.002)$, followed by the soil TN and clay contents (Fig. 4c). The litter $\mathrm{C} / \mathrm{N}$ was the main influences on the variations in the soil microbial communities in the temperate, and the soil N/P was the main influences in the warm temperate and subtropical forests. The microbial communities were also influenced by $\mathrm{ST}, \mathrm{pH}$, and SMC. 

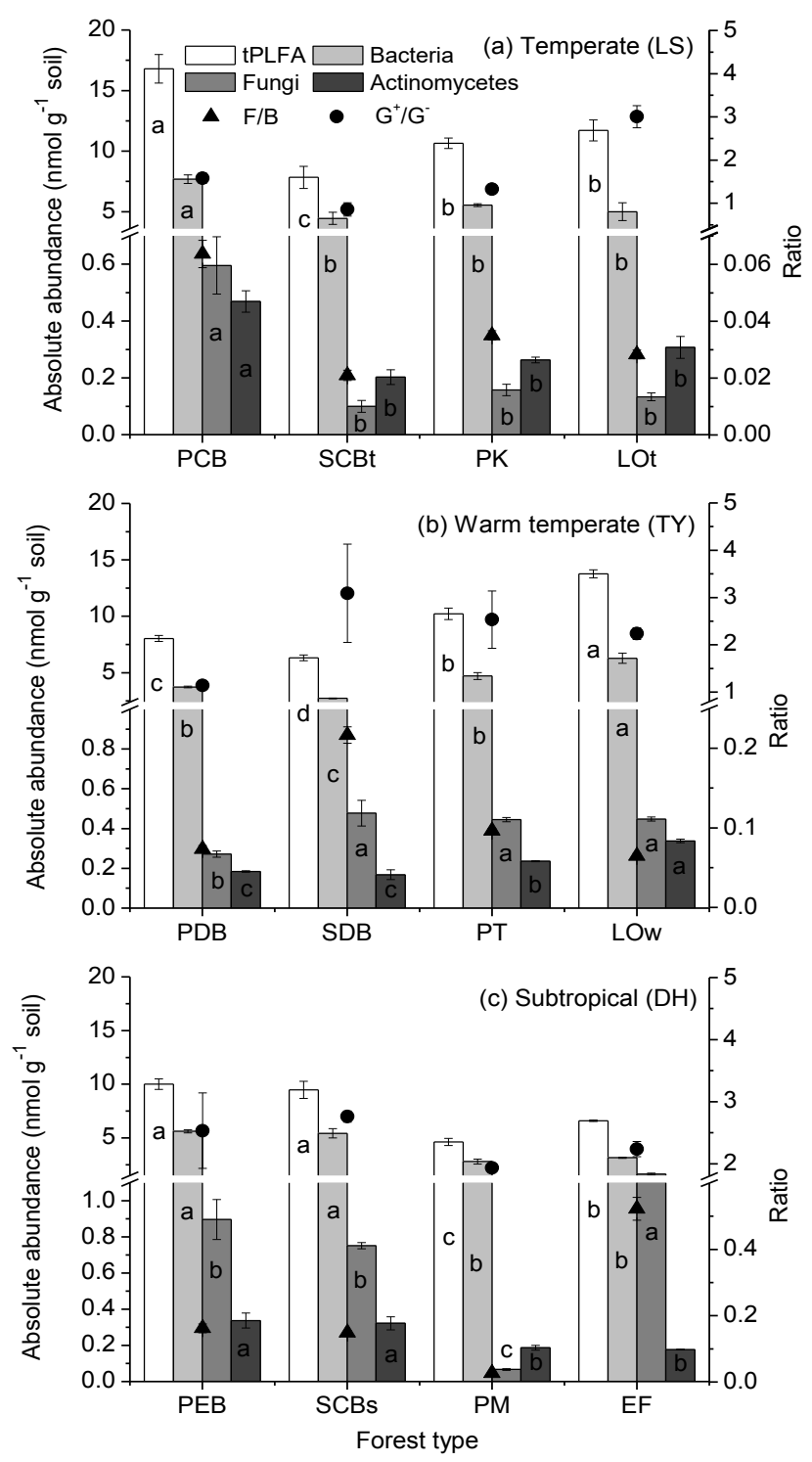

Figure 2. The PLFA contents, fungi / bacteria ratios, and $G^{+} / G^{-}$ for different forest types in different climatic zones (a Liangshui; b Taiyue; c Dinghu). Different lowercase letters indicate significant differences among forests in the same climatic zone. F / B fungi / bacteria; $G^{+} / G^{-}$- gram-positive bacteria/gram-negative bacteria. The abbreviations of the sampling sites are shown in Table 1.

\section{Discussion}

\subsection{Response of soil enzyme activities and microbial PLFAs to variations in forest type}

Forests in the same climate zone developed similar microbe functions which confirmed the result that the effect of climate on soil enzyme activities were stronger than the forest type and their interactive effect. However, there were still differ- ences among the enzyme activities in different forest types of the same climate zone. Soil microorganisms are usually considered to be $\mathrm{C}$ limited, and the litter inputs with a high $\mathrm{C} / \mathrm{N}$ ratio of PCB in the temperate zone will stimulate microbes to grow and secrete more enzymes (Table 1). Therefore, all enzyme activities were highest in PCB in the temperate zone. The high soil BG enzyme activities in the LOw forest in the warm temperate zone reflect the litter inputs with low $\mathrm{C}$ because soil enzyme activities will not continuously increase or decrease as nutrient availability increases or decreases. When the soil nutrients are short in supply, microbes will potentially increase the production of nutrient-acquiring enzymes because they are expected to optimize the allocation of their resource reserves by acquiring the resource that is most limiting (Bloom et al., 1985; Table 1). The soil enzyme activities were highest in the SCBs forest, reflecting the higher soil nutrient concentrations in subtropical zones.

The interactive effect of climate and forest type were more important than the individual effect of them. Therefore, the soil microbial communities of the 12 forests were separated from each other. Vegetation transfers substrate material of varying quality to microbes through litter fall. Fungi are more suitable for life in environments containing higher $\mathrm{C} / \mathrm{N}$ ratios and low soil pH (Nilsson et al., 2012). The four broadleaved forests were high in litter $\mathrm{C} / \mathrm{N}$ ratio (Table 1). Therefore, fungi were dominated in this harsh nutrient environments. The litter and soil from conifer broad-leaved mixed forest were high in $\mathrm{C}, \mathrm{N}$, and $\mathrm{P}$, and promote the propagation of bacteria that favor high-nutrient soil (Priha and Smolander, 1997; Priha et al., 2001). Therefore, the structures and functions of the soil microbial communities that developed in the different types of forest were unique.

\subsection{Common influences on soil enzyme activities and microbial communities}

Many other studies have reported how different factors determine the response of the soil microbial community and function to variations in forests (Högberg et al., 2007; McGuire et al., 2012). Mostly limited to one climatic zone, these studies were quite diverse and featured a range of microbial methods, sampling times, and environmental properties, which means it is difficult to compare the results. In this study, we collected the samples at the same times and used the same methods to analyze the soil microbial communities and enzyme activities. We found that ST, SMC, soil $\mathrm{pH}$, and soil $\mathrm{N} / \mathrm{P}$ ratio influenced, but perhaps did not dominate, the responses of the soil microbial community structures and enzyme activities in the different forest types across the three climatic zones.

Temperature can influence enzyme activity directly and indirectly by modifying the enzyme kinetics and influencing the proliferation of microbes, respectively (Kang et al., 2009). By changing the quality and quantity of the substrate on which microbes function, soil moisture is an important 

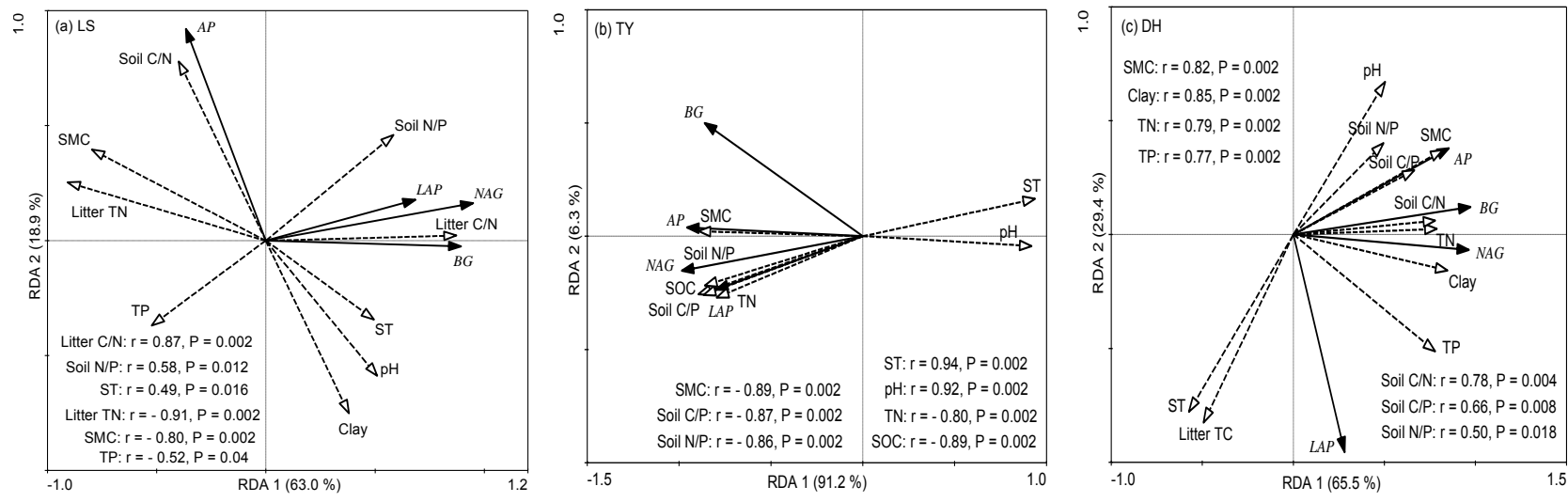

Figure 3. Redundancy analysis (RDA) ordination biplot of soil enzyme activities and environmental properties for the different forest types in different climatic zones (a Liangshui; b Taiyue; c Dinghu). Only the environmental variables that were significantly correlated with RDA1 are shown. The dotted lines and solid lines represent the environmental variables and enzyme activities. The variables in this table were abbreviated as follows: TC(litter) - litter total carbon; TN(litter) - litter total nitrogen; C / N(litter) - litter total carbon/nitrogen; ST - soil temperature; SMC - soil moisture content; Clay - soil clay content; SOC - soil organic carbon; TN - soil total nitrogen; TP - soil total phosphorus; C / N - soil carbon/nitrogen; C / P - soil carbon/phosphorus; and N / P - soil nitrogen/phosphorus.
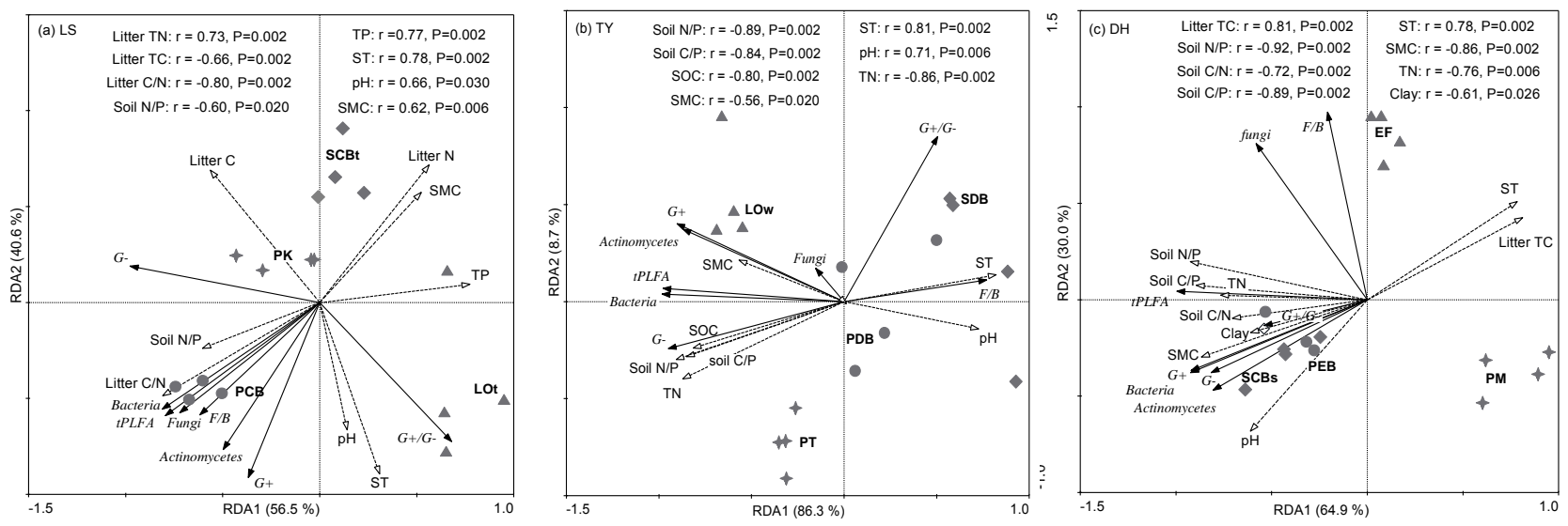

Figure 4. Redundancy analysis (RDA) ordination biplot of soil microbial community structure and environmental properties for different forest types in different climatic zones (a Liangshui; b Taiyue; c Dinghu). Only the environmental variables that were significantly correlated with RDA1 are shown. The dotted lines and solid lines represent the environmental variables and lipid signatures. The abbreviations of the variables included in this figure are shown in Fig. 3.

driver of the overall microbial composition and soil microbial function (Hackl et al., 2005). The responses of soil enzyme activities and microbial communities in the various forest types were all significantly influenced by the SMC in the three climatic zones. Increases in soil moisture can enhance both the release and the diffusion rates of enzymes, substrates, and reaction products (Burns et al., 2013), and our results showed that soil enzyme activities and microbial PLFAs increased as the SMC increased in the warm temperate and subtropical zones. However, water-logged conditions are not suitable for microbes and are not beneficial for the release of soil enzymes (Lucas-Borja et al., 2012), and, similar to other studies, soil enzyme activities and SMC were negatively correlated in the temperate zone forests (Brockett et al.,
2012). As the SMC increases, the bacterial PLFAs increase (Myers et al., 2001) and fungal PLFAs decrease (Staddon et al., 1998), which indicates that the soil microbial communities and enzyme activities in the different climatic zones were all influenced by the soil microclimate. This was also demonstrated by the stronger effect of climate on soil enzyme activities and the combined interaction effect of climate and forest type on soil microbial communities. Other studies have reported that precipitation and mean annual temperature played important roles in explaining the large-scale distribution of soil microbial community composition and functions (de Vries et al., 2012; Xu et al., 2017).

Soil $\mathrm{pH}$ directly affects the activities of extracellular enzymes immobilized in the soil matrix, and the effect of soil 
$\mathrm{pH}$ on the soil microbial community and function reflects the influence of vegetation through changes in soil chemistry. Every enzyme has a well-defined optimal soil $\mathrm{pH}$ value (Sinsabaugh et al., 2008) that results from different levels of soil enzyme activities under different soil $\mathrm{pH}$ conditions. Soil $G^{+} / G^{-}$ratios were highest in the subtropical forest where $G^{-}$bacteria PLFAs were least abundant, which may reflect microbial growth strategies. The $G^{+}$bacteria are primarily $\mathrm{K}$ strategists that can survive over long periods in the soil under harsh conditions with lower soil pH (Andrews and Hall, 1986). Increased $\mathrm{pH}$ causes an increase in bacterial diversity and a shift in the bacterial community to more $G^{-}$and fewer $G^{+}$bacteria PLFAs (Wu et al., 2009; Shen et al., 2013).

\subsection{Key influences on soil enzyme activities and microbial communities}

Our results showed that the most important controls on the responses of soil microbial communities and enzyme activities to vegetation types varied across climatic zones. The litter quality and quantity contribute to the maintenance of soil fertility in forest ecosystems (Wang et al., 2011). In our study, and the $\mathrm{C} / \mathrm{N}$ ratios were highest, in litter from $\mathrm{PCB}$ stands (Table 1), which shows that the soil in the PCB was more N-limited than the other soils because of litter inputs with high $\mathrm{C} / \mathrm{N}$ ratios (Table 1). Therefore, the microbial $\mathrm{N}$ demand was highest in soil in the PCB forest, which resulted in higher NAG and LAP values. Plant litter has a strong influence on soil microbial composition and activity, as the litter decomposition process provides nutrients for microorganism growth through inputs of leaf litter (Attiwill and Adams, 1993), dying roots (Silver and Miya, 2001), and root secretion (Grayston et al., 1997). The litter from the mixed forests, represented in our study by $\mathrm{PCB}$, is more diverse than that from the pure forests, and so a wider variety of soil microbes participate in the decomposition process, so that the soil organic matter is richer and there are more soil microbial PLFAs, than in the other forest types. Fungi typically dominate $\mathrm{N}$-limited environments and the fungal biomass is positively related to the $\mathrm{C} / \mathrm{N}$ ratio (Nilsson et al., 2012). The fungi / bacteria ratio ( $\mathrm{F} / \mathrm{B}$ ratio) was therefore highest in the PCB forest where the litter $\mathrm{C} / \mathrm{N}$ values were highest.

Microbes obtain the nutrients they need to construct biomass by decomposing soil organic matter. Wallenius et al. (2011) found that the soil bacterial biomass was higher in forests where the soil organic matter concentrations were higher than in forests with low soil organic matter concentrations, and $\mathrm{Xu}$ et al. (2017) found positive relationships between soil enzyme activities and SOC and TN concentrations along the NSTEC. In line with the resource limitation model, and also confirmed by several other studies (Brockett et al., 2012), Schimel and Weintraub (2003) suggested that increases in $\mathrm{N}$ and $\mathrm{C}$ substrate availability might favor enzyme synthesis. Soil microorganisms, however, did not grow when the available $\mathrm{P}$ concentrations in soil were less than
$0.7 \mathrm{mg} \mathrm{kg}^{-1}$ and were stimulated by $\mathrm{P}$ additions (Zheng et al., 2009). Other studies have reported that $P$ additions stimulated the different PLFA microbial groups in soils (Dong et al., 2015). The soil TN and TP were lower in the warm temperate and subtropical zone than in the temperate zone in our study (Table 1), and these two kinds of nutrients were more likely limiting factors in warm temperate and subtropical forest (DeForest et al., 2012; Xu et al., 2017). Therefore, soil TN and TP are more important in warm temperate and subtropical forests than in temperate forests.

The soil $\mathrm{N} / \mathrm{P}$ ratio was the most important influence on the soil microbial communities and enzyme activities in the warm temperate and subtropical zone, which is consistent with the results of previous studies (Shen et al., 2013; Högberg et al., 2007). Soil stoichiometric C, N, and P ratios reflect the nutrient limitations of the ecosystems (Sterner and Elser, 2002) and should indicate soil organic matter mineralization and sequestration (Gundersen et al., 1998). Soil microorganisms obtain $\mathrm{C}, \mathrm{N}$, and $\mathrm{P}$ in such a way that enzyme release corresponds with the soil stoichiometric ratios of $\mathrm{C}$, $\mathrm{N}$, and $\mathrm{P}$. When supplies of $\mathrm{N}$ or $\mathrm{P}$ are limited, the activities of the enzymes that are responsible for nitrate or phosphate mineralization will be higher. Consistent with this discussion, soil enzyme activities in subtropical forests $(\mathrm{DH})$ responded positively to the soil $\mathrm{C} / \mathrm{N}$ and $\mathrm{N} / \mathrm{P}$ ratios.

Soil texture is a key property that affects the accessibility of organic matter to microbes and is an important determinant of soil moisture and nutrient availability and retention (Veen and Kuikman, 1990). Consistent with our results, Lagomarsino et al. (2012) reported that the activities of soil BG, AP, and NAG were higher in silt and clay fractions than in coarser fractions. This may be attributed to the presence of clay-humus-enzyme complexes in the finest soil fractions, and implies that physical protection affects soil enzyme activities. In addition, fine textured soils with higher silt and clay contents are known to be more conducive to bacterial growth than coarser soils because they have a greater water-holding capacity and higher nutrient availability and offer better protection against bacterial grazers (Carson et al., 2010). Therefore, soil enzyme activities and microbial PLFAs were highest in the SCBs forest with a fine texture. Except for SCBt in the temperate zone and PT in the warm temperate zone, the soil clay content were not significantly different among the other three forest types. However, the soil clay contents of the four forest types in the subtropical zone were significantly different from each other and important for variations in microbial communities and functions (Table 1).

\subsection{Implications for ecosystem modeling}

There is increasing recognition that, to improve climate models, microbial processes should be simulated (DeLong et al., 2011). As such, this study has three important implications. First, microbial datasets that have information about 
enzyme activities and soil microbial properties contribute to the improved parameterization of ecosystem models ( $\mathrm{Xu}$ et al., 2013). Information about the spatial patterns of, and factors that control, microbial properties and enzymatic activities can enrich the datasets that are used to parameterize models of microbial processes (Wang et al., 2013). Secondly, knowledge about microbial community structure and its environmental controls can give a better understanding of how microbes adapt to changing environments, which is the main direction of model development (Schimel and Schaeffer, 2012). Information about edaphic controls on microbial processes is critical for developing new modeling frameworks with improved links with field experimental data (Abramoff et al., 2018). Finally, the information generated in this study about the divergence of the dominant factors that control soil microbial properties across forests is extremely valuable for improving our understanding of soil microbial ecology and forest management.

\section{Conclusions}

In this study, we characterized the soil microbial communities and enzyme activities and factors that controlled them in various forest types across three different climatic zones. We found that forest types with specific soil conditions supported the development of distinct soil microbial communities with variable functions. The soil total PLFAs, bacteria, $G^{+}, G^{-}$, and actinomycete were much higher in the conifer broad-leaved mixed forests than in the coniferous forests and the broad-leaved forests. The soil BG and NAG activities were much higher in the coniferous forest than in the conifer broad-leaved mixed forests and the broad-leaved forests. Except for AP, soil enzyme activities were highest in the warm temperate zone. Soil tPLFAs, bacteria, and $G^{-}$increased from temperate zone to subtropical zone, but for fungi, the situation was the reverse. The litter TN, soil temperature, and soil clay contents were important predictors of the variance in soil enzyme activities in temperate, warm temperate, and subtropical zones, respectively, while litter and soil nutrient ratios were significant predictors of the variance in soil microbial communities. We also found that SMC, soil temperature, soil $\mathrm{pH}$, and the soil $\mathrm{N} / \mathrm{P}$ ratio were common drivers of variations in the soil microbial community structure and enzyme activities across the different forest types in the three climatic zones. Forests within the same climatic zones had similar soil microbial communities and enzyme activities, and these patterns were mainly determined by the litter input, soil micro-environment, and soil nutrient ratios. The data in this study are extremely valuable for improving our understanding of soil microbial ecology and forest management.
Data availability. Requests for data and materials should be addressed to Nianpeng He (henp@igsnrr.ac.cn) and Guirui Yu (yugr@igsnrr.ac.cn).

\section{The Supplement related to this article is available online at https://doi.org/10.5194/bg-15-1217-2018-supplement.}

Author contributions. ZWX, GRY, and XYZ planned and designed the research. ZWX, NPH, RLW, NZ, CCJ, and CYW conducted fieldwork. ZWX, GRY, XYZ, QFW, SZW, and XFX wrote the manuscript. All authors contributed critically to the drafts and gave final approval for publication.

Competing interests. The authors declare that they have no conflict of interest.

Acknowledgements. This research was jointly supported by the Key Program of the National Natural Science Foundation of China (31290221), the National Natural Science Foundation of China (41601084, 41571251), and the Fundamental Research Funds for the Central Universities (2412016KJ029). Xiaofeng Xu was grateful for the financial support from the San Diego State University and the Oak Ridge National Laboratory.

Edited by: Xinming Wang

Reviewed by: two anonymous referees

\section{References}

Abramoff, R., Xu, X., Hartman, M., O’Brien, S., Feng, W. T., Davidson, E. A., Finzi, A., Moorhead, D. L., Schimel, J. P., Torn, M. S., and Mayes, M. A.: The millennial model: in search of measurable pools and transformations for modeling soil carbon in the new century, Biogeochemistry,137, 51-71, 2018.

Andrews, J. H. and Hall, R. F.: R- and K-selection and microbial ecology, Advan. Microb. Ecol., 9, Springer US, 99-147, 1986.

Attiwill, P. M. and Adams, M. A.: Nutrient cycling in forests, New Phytol., 124, 561-582, 1993.

Bååth, E. and Anderson, T.H.: Comparison of soil fungal/bacterial ratios in a pH gradient using physiological and PLFA-based techniques, Soil Biol. Biochem., 35, 955-963, 2003.

Baumann, K., Dignac, M-F., Rumpel, C., Bardoux, G., Sarr, A., Steffens, M., and Maron, P. A.: Soil microbial diversity affects soil organic matter decomposition in a silty grassland soil, Biogeochemistry, 114, 201-212, 2013.

Bloom, A., Chapin, F. I., and Mooney, H.: Resource limitation in plants-an economic analogy, Annu. Rev. Ecol. Syst., 16, 363392, 1985.

Brockett, B. F. T., Prescott, C. E., and Grayston, S. J.: Soil moisture is the major factor influencing microbial community structure and enzyme activities across seven biogeoclimatic zones in western Canada, Soil Biol. Biochem., 44, 9-20, 2012. 
Burns, R. G., DeForest, J. L., Marxsen, J., Sinsabaugh, R. L., Stromberger, M. E., Wallenstein, M. D., Weintraub, M. N., and Zoppini, A.: Soil enzymes in a changing environment: Current knowledge and future directions, Soil Biol. Biochem., 58, 216234, 2013

Carson, J. K., Gonzalez-Quinones, V., Murphy, D. V., Hinz, C., Shaw, J. A., and Gleeson, D. B.: Low pore connectivity increases bacterial diversity in soil, Appl. Environ. Microbiol., 76, 39363942, 2010.

Chung, H., Zak, D. R., Reich, P. B., and Ellsworth, D. S.: Plant species richness, elevated $\mathrm{CO}_{2}$, and atmospheric nitrogen deposition alter soil microbial community composition and function, Glob. Change Biol., 13, 980-989, 2007.

DeLong, E. F., Harwood, C. S., Chisholm, P. W., Karl, D. M., Moran, M. A., Schmidt, T. M., Tiedje, J. M., Treseder, K. K., and Worden, A. Z.: Incorporating microbial processes into climate models, The American Academy of Microbiology, Washington, DC, 2011.

De Vries, F. T., Manning, P., Tallowin, J. R., Mortimer, S. R., Pilgrim, E. S., Harrison Kathryn A., Hobbs, P. J., Quirk, H., Shipley, B., Cornelissen, J. H. C., Kattge, J., and Bardgett, R. D.: Abiotic drivers and plant traits explain landscape-scale patterns in soil microbial communities, Ecol. Lett., 15, 1230-1239, 2012.

Dong, W. Y., Zhang, X. Y., Liu, X. Y., Fu, X. L., Chen, F. S., Wang, H. M., Sun, X. M., and Wen, X. F.: Responses of soil microbial communities and enzyme activities to nitrogen and phosphorus additions in Chinese fir plantations of subtropical China, Biogeosciences, 12, 5537-5546, https://doi.org/10.5194/bg-125537-2015, 2015.

Grayston, S. J. and Prescott, C. E.: Microbial communities in forest floors under four tree species in coastal British Columbia, Soil Biol. Biochem., 37, 1157-1167, 2005.

Grayston, S. J., Vaughan, D., and Jones, D.: Rhizosphere carbon flow in trees, in comparison with annual plants: the importance of root exudation and its impact on microbial activity and nutrient availability, Appl. Soil Ecol., 5, 29-56, 1997.

Gundersen, P., Callesen, I., and Vries, W.D.: Nitrate leaching in forest ecosystems is related to forest floor C / $\mathrm{N}$ ratios, Environ. Pollut., 102, 403-407, 1998.

Hackl, E., Pfeffer, M., Donat, C., Bachmann, G., and Zechmeisterboltenstern, S.: Composition of the microbial communities in the mineral soil under different types of natural forest, Soil Biol. Biochem., 37, 661-671, 2005.

Hannam, K., Quideau, S., and Kishchuk, B.: Forest floor microbial communities in relation to stand composition and timber harvesting in northern Alberta, Soil Biol. Biochem., 38, 2565-2575, 2006.

Högberg, M. N., Högberg, P., and Myrold, D. D.: Is microbial community composition in boreal forest soils determined by $\mathrm{pH}, \mathrm{C}$ to-N ratio, the trees, or all three, Oecologia, 150, 590-601, 2007.

Huang, X., Liu, S., Wang, H., Hu, Z., Li, Z., and You, Y.: Changes of soil microbial biomass carbon and community composition through mixing nitrogen-fixing species with Eucalyptus urophylla in subtropical China, Soil Biol. Biochem., 73, 42-48, 2014.

Huang, Z., Clinton, P. W., Baisden, W. T., and Davis, M. R.: Longterm nitrogen additions increased surface soil carbon concentration in a forest plantation despite elevated decomposition, Soil Biol. Biochem., 43, 302-307, 2011.
Kang, H., Kang, S., and Lee, D.: Variations of soil enzyme activities in a temperate forest soil, Ecol. Res., 24, 1137-1143, 2009.

Lagomarsino, A., Grego, S., and Kandeler, E.: Soil organic carbon distribution drives microbial activity and functional diversity in particle and aggregate-size fractions, Pedobiologia, 55, 101-110, 2012.

Lauber, C. L., Strickland, M. S., Bradford, M. A., and Fierer, N.: The influence of soil properties on the structure of bacterial and fungal communities across land-use types, Soil Biol. Biochem., 40, 2407-2415, 2008.

Li, H., Wang, X., Liang, C., Hao, Z., Zhou, L., Ma, S., Li, X. B., Yang, S., Yao, F., and Jiang, Y.: Aboveground-belowground biodiversity linkages differ in early and late successional temperate forests, Sci Rep-UK, 5, 12234, 2015.

Liu, L., Gundersen, P., Zhang, T., and Mo, J. M.: Effects of phosphorus addition on soil microbial biomass and community composition in three forest types in tropical China, Soil Biol. Biochem., 44, 31-38, 2012.

Lucas-Borja, M. E., Candel Pérez, D., López Serrano, F. R., Andrés, M., and Bastida, F.: Altitude-related factors but notPinuscommunity exert a dominant role over chemical and microbiological properties of a Mediterranean humid soil, Eur. J. Soil Sci., 63, 541-549, 2012.

McGuire, K. L., Fierer, N., Bateman, C., Treseder, K. K., and Turner, B. L.: Fungal community composition in neotropical rain forests: the influence of tree diversity and precipitation, Microb. Ecol., 63, 804-812, 2012.

Mitchell, R. J., Hester, A. J., Campbell, C. D., Chapman, S. J., Cameron, C. M., Hewison, R. L., and Potts, J. M.: Is vegetation composition or soil chemistry the best predictor of the soil microbial community, Plant Soil, 333, 417-430, 2010.

Myers, R. T., Zak, D. R., White, D. C., and Peacock, A.: Landscapelevel patterns of microbial community composition and substrate use in upland forest ecosystems, Soil Sci. Soc. Am. J., 65, 359367, 2001.

Nilsson, L. O., Wallander, H., and Gundersen, P.: Changes in microbial activities and biomasses over a forest floor gradient in C-to-N ratio, Plant Soil, 355, 75-86, 2012.

Priha, O. and Smolander, A.: Microbial biomass and activity in soil and litter under Pinus sylvestris, Picea abies and Betula pendula at originally similar field afforestation sites, Biol. Fert. Soils, 24, 45-51, 1997.

Priha, O., Grayston, S. J., Hiukka, R., Pennanen, T., and Smolander, A.: Microbial community structure and characteristics of the organic matter in soils under Pinus sylvestris, Picea abies and Betula pendula at two forest sites, Biol. Fert. Soils, 33, 17-24, 2001.

Saiya-Cork, K. R., Sinsabaugh, R. L., and Zak, D. R.: The effects of long term nitrogen deposition on extracellular enzyme activity in an Acer saccharum forest soil, Soil Biol. Biochem., 34, 13091315, 2002.

Scheibe, A., Steffens, C., Seven, J., Jacob, A., Hertel, D., Leuschner, C., and Gleixner, G.: Effects of tree identity dominate over tree diversity on the soil microbial community structure, Soil Biol. Biochem., 81, 219-227, 2015.

Schimel, J. P. and Schaeffer, S. M.: Microbial control over carbon cycling in soil, Front. Microbiol., 3, 1-11, 2012. 
Schimel, J. P. and Weintraub, M. N.: The implications of exoenzyme activity on microbial carbon and nitrogen limitation in soil: a theoretical model, Soil Biol. Biochem., 35, 549-563, 2003.

Shen, C., Xiong, J., Zhang, H., Feng, Y., Lin, X., Li, X., Liang, W. J., and Chu, H. Y.: Soil pH drives the spatial distribution of bacterial communities along elevation on Changbai Mountain, Soil Biol. Biochem., 57, 204-211, 2013.

Silver, W. L. and Miya, R. K.: Global patterns in root decomposition: comparisons of climate and litter quality effects, Oecologia, 129, 407-419, 2001.

Sinsabaugh, R. L., Lauber, C. L., Weintraub, M. N., Ahmed, B., Allison, S. D., Crenshaw, C. Contosta, A. R., Cusack, D., Frey, S., Gallo, M. E., Gartner, T. B., Hobbie, S. E., Holland, K.i, Keeler, B. L., Powers, J. S., Stursova, Takacs-Vesbach, C., Waldrop, M. P., Wallenstein, M. D., Zak, D. R., and Zeglin, L. H.: Stoichiometry of soil enzyme activity at global scale, Ecol. Lett., 11, 12521264, 2008.

Six, J., Elliott, E. T., and Paustian, K.: Soil structure and soil organic matter: II. A normalized stability index and the effect of mineralogy, Soil Sci. Soc. Am. J., 64, 1042-1049, 2000.

Soil Survey Staff: Keys to Soil Taxonomy, 11th Edn., Natural Resources Conservation Service, Washington, DC, 2010.

Staddon, W. J., Trevors, J. T., Duchesne, L. C., and Colombo, C. A.: Soil microbial diversity and community structure across a climatic gradient in western Canada, Biodivers. Conserv., 7, 10811092, 1998.

Sterner, R. W. and Elser, J. J.: Ecological stoichiometry: the biology of elements from molecules to the biosphere, Princeton University Press, 2002.

Ter Braak, C. J. F., and Smilauer, P.: CANOCO Reference manual and CanoDraw for Windows User's guide: Software for Canonical Community Ordination (Version 4.5), 2002.

Tripathi, B. M., Kim, M., Tateno, R., Kim, W., Wang, J., Lai-Hoe, A, Shukor, N. A., Rahim, R. A., Go, R., and Adams, J. M.: Soil $\mathrm{pH}$ and biome are both key determinants of soil archaeal community structure, Soil Biol. Biochem., 88, 1-8, 2015.

Ultra, V. U., Han, S.-H., and Kim, D.-H.: Soil properties and microbial functional structure in the rhizosphere of Pinus densiflora (S. and $\mathrm{Z}$.) exposed to elevated atmospheric temperature and carbon dioxide, J. Forest Res., 18, 149-158, 2013.

Urbanová, M., Šnajdr, J., and Baldrian, P.: Composition of fungal and bacterial communities in forest litter and soil is largely determined by dominant trees, Soil Biol. Biochem, 84, 53-64, 2015.

Ushio, M., Kitayama, K., and Balser, T. C.: Tree species effects on soil enzyme activities through effects on soil physicochemical and microbial properties in a tropical montane forest on Mt. Kinabalu, Borneo, Pedobiologia, 53, 227-233, 2010. van Dam, N. M. and Heil, M.: Multitrophic interactions below and above ground: en route to the next level, J. Ecol., 99, 77-88, 2011.

van der Heijden, M. G., Bardgett, R. D., and van Straalen, N. M.: The unseen majority: soil microbes as drivers of plant diversity and productivity in terrestrial ecosystems, Ecol. Lett., 11, 296310, 2008.

Veen, J. A. V. and Kuikman, P. J.: Soil structural aspects of decomposition of organic-matter by micro-organism, Biogeochemistry, 11, 213-233, 1990.

Wallenius, K., Rita, H., Mikkonen, A., Lappi, K., Lindström, K., Hartikainen, H., Raateland, A., and Niemi, R. M.: Effects of land use on the level, variation and spatial structure of soil enzyme activities and bacterial communities, Soil Biol. Biochem., 43, 1464-1473, 2011.

Wang, C., Han, G., Jia, Y., Feng, X., Guo, P., and Tian, X.: Response of litter decomposition and related soil enzyme activities to different forms of nitrogen fertilization in a subtropical forest, Ecol. Res., 26, 505-513, 2011.

Wang, G., Post, W. M., and Mayes, M. A.: Development of microbial-enzyme-mediated decomposition model parameters through steady-state and dynamic analyses, Ecol. Appl., 23, 255272, 2013.

Wu, Y., Ma, B., Zhou, L., Wang, H., Xu, J., Kemmitt, S., and Brookes, P. C.: Changes in the soil microbial community structure with latitude in eastern China, based on phospholipid fatty acid analysis, Appl. Soil Ecol., 43, 234-240, 2009.

Xu, X., Thornton, P. E., and Post, W. M.: A global analysis of soil microbial biomass carbon, nitrogen and phosphorus in terrestrial ecosystems, Global Ecol. Biogeogr., 22, 737-749, 2013.

Xu, Z., Yu, G., Zhang, X., Ge, J., He, N., Wang, Q., and Wang, D.: The variations in soil microbial communities, enzyme activities and their relationships with soil organic matter decomposition along the northern slope of Changbai Mountain, Appl. Soil Ecol., 86, 19-29, 2015.

Xu, Z. W., Yu, G. R., Zhang, X. Y., He, N. P., Wang, Q. F., Wang, S. Z.,Wang, R. L., Zhao, N., Jia, Y. L., and Wang, C. Y.: Soil enzyme activity and stoichiometry in forest ecosystems along the North-South Transect in eastern China (NSTEC), Soil Biol. Biochem., 104, 152-163, 2017.

Zheng, M., Huang, J., Chen, H., Wang, H., and Mo, J.: Responses of soil acid phosphatase and beta-glucosidase to nitrogen and phosphorus addition in two subtropical forests in southern China, Eur. J. Soil Biol., 68, 77-84, 2015. 